\title{
The Determinate of Agricultural Export in Ethiopia: An Error Correction Modle and Cointegration Approach
}

\author{
Israel Bereket \\ Department of Economics, College of Business and Economics, \\ Jinka University, Jinka, Ethiopia
}

\begin{abstract}
This paper identified some of the main determinants of agricultural export in Ethiopia for The period 1993-2013. To test empirically the relationship between agricultural export performance and its major selected determinants such as real gross domestic product, real effective exchange rate, fertilizer input, trade openness, institutional quality and export diversification; cointegration and error correction approaches in the regression analysis were used. The results from the cointegration and error correction models revealed that real GDP, fertilizer input and export diversification are significantly affected agricultural export performance in the long run except real effective exchange rate, trade openness and institutional quality. In the short run, real gross domestic product (RGDP), real effective exchange rate, and export diversification became significant. On the other hand, out of the variables significantly affected agricultural export both in the long run and short run; real GDP and export diversification affected agricultural export positively as expected.
\end{abstract}

DOI: $10.7176 / \mathrm{JESD} / 11-3-05$

Publication date: February $29^{\text {th }} 2020$

\section{INTRODUCTION}

\subsection{Back ground of the study}

The structure of Ethiopian economy is divided in to three major sector; namely, the agriculture, industry and service sector. Agriculture is the main stay of the country economy. It generates the lion's share of the country GDP. For instance, during 2010/2011 about $45.3 \%$ of the country's GDP came from the agricultural sector the allied activities such as forestry and fishery. The least contributor to GDP is the industrial sector, comprising mining and quarrying, manufacturing, electricity and water, and construction. In 2010/2011 the service sector represented $44.1 \%$ of the country's GDP. Regarding sectoral development, as of 2010/2011 agriculture grew by $9 \%$, industry by $15 \%$ and service by $12.5 \%$ (NBE, 2013).

A country which is dependent on the export of primary product is deemed to have lower growth prospects this happen as a result of both the unfavourable world demand and the low income elasticity of demand in the economy for such product. On the supply side, the combined effects of lower skills and technology contents of primary commodity production and its negligible linkage with the rest of the economy result in lower growth (Bengali and Fukasak, 2013).

Hence, similar to other African countries, agriculture is by far the single most important economic activity in Ethiopia and it remains key to achieving the poverty target of the MDGs. The agriculture sector is very important for Ethiopian for a number of reasons first; currently agriculture is source of livelihood for the overwhelming majority of Ethiopians. In addition agriculture's contribution to the national economy (in terms of share of GDP) and export is large (Ibrahim, 2006).

According to Ministry of Foreign Affairs (2011) the first objective of Ethiopian foreign trade policy is developing and enhancing broad international market for the country's agricultural products in particular which shows the country's export is almost entirely agricultural product and the export promotion strategy of Ethiopia is upheld by three main pillars from these pillars, focusing on the limited number of the priority exportable products which are selected exportable agricultural products in medium terms. The leading export product where (coffee contributing $36 \%$, pulses, oil seeds and spices $22.6 \%$, chat $7.8 \%$ and hide, skin and leather products $7.6 \%$ ). In absolute terms this products cover around $75 \%$ of the total export earnings.

\subsection{Statement of the problem}

Ethiopia has great agricultural potential because of its vast area of fertile land, diverse climate, generally adequate rain fall and large labor force. Despite this potential, however, Ethiopian agriculture has remained underdeveloped. Because of drought, which repeatedly affected the country since the early 1970's, a poor economic base (low productivity, weak information and low level of technology), and over population, the agricultural sectors has performed poorly but this major sector which directly affect the export has shown some improvements in the past two decades but there is still room for improvement (IMF, 2010).

According to Samual (2012) made an attempt to identify the factors that determine agricultural export performance of Ethiopia. By including variables such as terms of trade, gross domestic product, domestic price, world price, nominal effective exchange rate, paved roads and fertilizer input. The regression result shows that 
domestic price was insignificant in the short run. In addition to domestic price, gross domestic product also became insignificant. That means in the short run these variables have no impact on the agricultural export performance of Ethiopia. On the other hand except these two explanatory variables all other variables such as terms of trade, world price, kilometers of paved roads, and fertilizer input import over a period were found to affect the dependent variable significantly and positively as already anticipated. The coefficient of nominal effective exchange rate was negative despite its significance.

According to Diana (2014) the major determinants of agricultural export he includes variable such as real GDP, infrastructural development, openness, real effective exchange rate and fertilizer input. The result of this study shows in the long run fertilizer input and infrastructure significantly affects agricultural export performance of Ethiopia and in the short run all variable (real GDP, infrastructural development, openness, real effective exchange rate and fertilizer inputs) are insignificant.

All the above studies undertaken on the demand and supply side are focus on the variables such as terms of trade, GDP, world price, effective exchange rate, infrastructural development, fertilizer input, per capita GNI, foreign direct investment and openness as the determinant of agricultural export rather they don't take in to consideration export diversification. Therefore, this study tries to show by adding export diversification as one of the supply side determinant of agricultural export in Ethiopia.

\section{3 objective of the study}

The general objective of this study is examining the determinant of Ethiopia's agricultural export. The specific objectives of the study are:

$>$ To assess the impact of export diversification on the agricultural export.

$>$ To examine the effect of institutional quality on the agricultural export.

$>$ To examine the effect of fertilizer input on the agricultural export.

\subsection{Scope and limitation of the study}

The analysis of this paper involves an examination of the determinants of agricultural export for the period between 1993 and 2013. The study is limited to this period due to time limitation, and at the same time not to vast study.

\section{Data sources, Methodology and Model specification}

The data used for the study is time series and econometrics analysis and applied by using ordinary least square (OLS) regression. Secondary source of data are applied and the principal sources are the National Bank of Ethiopia, Ministry of Finance and Economic Development (MoFED) and central statistical Authority (CSA).

\section{Model specification}

The adopted model takes Agricultural export is the main variables. Gross domestic product, real exchange rate, agricultural input supply (fertilizer input), institutional quality, trade openness and export diversification are other control or explanatory variables. A time series data analysis follows with a regression models to capture specific effects.

Therefore the mathematically relationship between the agricultural export and other included determinate variable are expressed as follows:

$\ln$ AGREXP $_{t}=\quad f(\operatorname{lnRGDP}, \operatorname{lnREER}, \ln F E R T$, OPP, IQ, InDINDEX)

Inagrexp $=\beta_{0}+\beta_{1} \ln$ GDPt $+\beta_{2} \ln r e e r t+\beta_{3} \operatorname{lnfertt}+\beta_{40 p p_{t}}+\beta_{5}$ iq $_{t}+\beta_{6} \operatorname{lndindex} t+e_{i}$

$\operatorname{lnagrex}_{\mathbf{t}}=$ agricultural export in million. $_{\text {. }}$

InrGDPt $=$ value of gross domestic product in millions of birr,

Inreert $=$ real effective exchange rate at time $t$,

$\mathbf{o p p}_{\mathbf{t}}=$ a proxy for degree of openness at time $t$,

Infertt $=$ fertilizer import over a period in thousands of birr,

$\mathbf{i q} \mathbf{t}=$ institutional quality at time $\mathbf{t}$,

Indindex $\mathbf{t}=$ diversification index at time $t$,

\subsection{Description of variables and expected sign.}

\section{Real effective exchange rate (REER)}

Exchange rates play a central role in international trade because they allow the computation of the relative prices of goods and services produced in different countries thereby allowing the comparison of those prices across countries.

\section{Gross domestic product (GDP)}

Kumar (1998) in his study on the determinants of export growth in developing countries confirmed that GDP has a significant positive impact export volumes. Therefore, we expect the sign of the coefficient of GDP, $b_{1}$, to be positive. 


\section{Trade openness (OPP)}

If a country sets a policy of high trade tariffs, thus restricting the desirability of international trade, this restrictive policy will inhibit other countries from sending exports and accepting imports from that country. Therefore, we expect the sign of the coefficient opp, $b_{4}$, to be positive.

\section{Fertilizer input (FERT)}

Fertilizer is the ingredient which increases the productivity of agricultural products. When fertilizer import increases, its consumption will also increase which in turn increases the productivity and hence increases export supply of the country. Hence, we expect the sign of the coefficient of fertilizer input import, $b_{3}$, to be positive.

\section{Institutional Quality (IQ)}

Institutional quality, according to World Bank, is reflected by variables such as rule of law, property right, investment procedure, financial freedom, and freedom from corruption. A country with better institutional set up will export more. We therefore expect the coefficient of, b5, to be positive.

\section{Export diversification index (DINDEX)}

Greater diversification of the productive structure would imply, ceteris paribus, more higher-value added activities especially for those developing countries dedicated to the export of agricultural commodities, and adds more to the volume of exports. Therefore, the sign of the coefficient is expected for Dindex, $b_{6}$, to be positive.

\subsection{Diagnostics test}

\subsubsection{Normality test}

The result of Skewness /Kurtosis tests for Normality shows that agricultural export, real gross domestic product, real exchange rate, trade openness, institutional quality and export diversification and also the residual are normally distributed.

\subsubsection{Model specification test}

Ramsey RESET test used to test of regression model specification. It performs a regression specification error test (RESET) for omitted variables. The result in this study shows that: we would have accept the null hypothesis which states that model has no omitted variables and reject the alternative hypothesis which state that has omitted variables.

\subsubsection{Test for Stationarity}

This study uses dickey fuller (DF) test to analysis or investigate stationary of Variables. If the calculated dickey fuller is greater than the tabulated (critical) value at a given level, the time series variable is stationary at the given order.

The unit root test result of the variables is presented in the following table.

Table 2.1 stationary test result

\begin{tabular}{|l|l|l|}
\hline Variable & $\begin{array}{c}\text { Test } \\
\text { Statistic }\end{array}$ & Stationary at \\
\hline Dlnagrexp & $-5.042^{*}$ & First difference \\
\hline Dlnrgdp & $-3.015^{* *}$ & First difference \\
\hline Dlnreer & $-4.153^{*}$ & First difference \\
\hline Dlnfert & $-3.030^{* *}$ & First difference \\
\hline Dopp & $-3.263^{*}$ & First difference \\
\hline Diq & $-5.198^{*}$ & First difference \\
\hline Dlndindex & $-5.435^{*}$ & First difference \\
\hline \multicolumn{2}{|l}{$1 \%$ critical value $=-3750$} & \\
\hline \multicolumn{2}{|l|}{ critical value $=-3.000$} & \\
\hline
\end{tabular}

NB: * significant at $1 \%, * *$ significant at $5 \%$

Source: stata results

The result in Table 2.1 shows that all there are I(1)but not any order zero. As we have seen form table 2.1, agrexp, rgdp, reer, fert, opp, iq and dindex are integrated of order one I(1). Meaning agrexp, rgdp, reer, fert, opp, iq and dindex are stationary at first difference

\subsubsection{Co integration}

A linear combination of a time series variable becomes stationary if there is co-integration relationship between the variables. The residual is stationary at $1 \%$ level of significant as shown in the following table. Therefore, the variables are co-integrated and there is long run relationship between them. 
Table 2.2 co-integration test results

\begin{tabular}{|l|l|l|}
\hline Variable & Test Statistic & Stationary at \\
\hline Residual & $-5.499^{*}$ & Level \\
\hline $1 \%$ critical value $=-3750$ & \\
$5 \%$ critical value $=-3.000$ & \\
$10 \%$ critical value $=-2.630$ & \\
\hline
\end{tabular}

\section{$\mathrm{NB}$; significant at $1 \%$}

Since AEG test result is -5.499 it is stationary at $1 \%$ level $\mathrm{I}(0)$, which means the variables are stationary. This shows the existence of long run relationship among the variables.

\subsubsection{Autocorrelation Test}

The Durbin-Watson statistic is always between 0 and 4. Therefore, as a rule of thumb, if Durban Watson dstatistic is found nearer to the value 2 in an application, one may assume that there is no first order autocorrelation, either positive or negative. Values approaching 0 indicate positive autocorrelation and values approaching toward 4 indicate negative autocorrelation (Gujarati, 2004).

The result of this study shows that there is no autocorrelation problem in this model.

DW $(7,21)=1.666559$

\subsubsection{Heteroskedasticity Test}

The homoskedasticity assumption states that the variance of unobservable error $E i$ conditional on explanatory variable is constant. The test has given the following results by using Breusch Pagan test. The result of this study shows that since p-value is greater than $5 \%(0.9885>0.05)$, the null hypothesis is accepted i.e. no problem of hetroskedasticity

\subsubsection{Multicolinearity Test}

The Variance Inflation Factor (VIF) is a statistic that can be used to identify multicolinearity in a matrix of predictor variables. The decision rule of multicollinearity as a rule of thumb states that the VIF $<10$ shows absence of multicollinearity.

Table 2.3 Multicolinearity test (VIF)

\begin{tabular}{|l|r|c|}
\hline Variable & VIF & $1 /$ VIF \\
\hline lnrgdp & 23.86 & 0.041903 \\
\hline Opp & 13.66 & 0.073217 \\
\hline lndindex & 5.10 & 0.196079 \\
\hline Iq & 4.65 & 0.215155 \\
\hline Lnreer & 3.49 & 0.286447 \\
\hline lnfert & 2.55 & 0.392623 \\
\hline Mean VIF & \multicolumn{2}{|l|}{} \\
\hline
\end{tabular}

the mean VIF is less than ten $(8.88 \leqslant 10)$, implying that there is no multicollinearity problem.

\subsection{Result and discussion}

\subsubsection{Long run model estimation}

From the table above (table 2.1) the residual is stationary at $1 \%$ significant level shows the presence of long run relationship between the dependent and independent variables. Accordingly from the estimation, the following results are obtained for the long run model.

The long run estimation model reveals that the coefficient of determination which is denoted by $\boldsymbol{R}^{2}$ is 0.9908 or 99.0 percent. Its meaning is that 99.0 percent of the variation in agrexp is explained by the given variable jointly included in the model. The remaining $1.0 \%$ of the variation is presumed to be due to random variability. 
Vol.11, No.3, 2020

Table 2.4 long run estimation results Dependent variable Agricultural Export

\begin{tabular}{|c|c|c|c|c|c|c|}
\hline Variable & Coef. & Std. Err. & $\mathrm{t}$ & $\mathrm{P}>\mathrm{t}$ & \multicolumn{2}{|c|}{ [95\% Conf. Interval] } \\
\hline $\ln r g d p$ & 3.545981 & .3185633 & $11.13^{*}$ & 0.000 & 2.86273 & 4.229231 \\
\hline lnreer & -.4671589 & .2705075 & -1.73 & 0.106 & -1.04734 & .113022 \\
\hline lnfert & .096287 & .0455689 & $2.11 * *$ & 0.053 & -.0014486 & .1940227 \\
\hline opp & -2.479366 & 1.678813 & -1.48 & 0.162 & -6.080062 & 1.12133 \\
\hline $\mathrm{iq}$ & -.0045902 & .0044373 & -1.03 & 0.318 & -.0141072 & .0049269 \\
\hline lndindex & 4.077307 & .7559493 & $5.39 *$ & 0.000 & 2.455957 & 5.698657 \\
\hline cons & -32.06849 & 4.22051 & -7.60 & 0.000 & -41.12059 & -23.0164 \\
\hline $\begin{array}{l}\text { Number of } \\
F(6, \quad 14) \\
\text { Prob > F } \\
\text { R-squared }\end{array}$ & $\begin{array}{r}\mathrm{bs}=21 \\
251.40 \\
=0.0000 \\
=0.9908\end{array}$ & & $\begin{array}{l}\text { Adj R-sc } \\
\text { Root MS } \\
\text { Prob >c } \\
\text { DW ( } 7,\end{array}$ & $\begin{array}{r}=0.9 \\
=\quad .13 \\
0.988 \\
=1.6\end{array}$ & & \\
\hline
\end{tabular}

The estimated long run model results shows that the real gross domestic product, agriculture input supply (fertilizer input) and export diversification index are statistically significant and the remaining trade openness, real effective exchange rate and institutional quality are statistically insignificant. The value of constant term, 32.06849 which is also the intercept of agricultural export and it is statistically significant, interpreted as the value that we would predict for agrexp if all the explanatory variables included in the model are zero. However, this is only a meaningful interpretation if it is reasonable that the entire explanatory variable included in the model can be zero (0), and if the data set actually included values for predictor variable that were near 0 . If neither of these conditions is true, then the constant term really has no meaningful interpretation.

As shown in table 2.4 above, in the long run real GDP has a positive and significant impact on Agrexp. The estimated result shows that holding other variable constant, a $1 \%$ increase in real GDP will cause increase in Agrexp by $3.545981 \%$.

The sign of the coefficient of real effective exchange rate is negative as expected. The insignificance of this variable reiterates that depreciating real effective exchange rate does not enhance the competitiveness of the agricultural export of Ethiopia in the international market. Therefore, depreciation of exchange rate is little to do with improving the countries agricultural export.

Also impact of agricultural input use (captured by fertilizer input) is positive and the significance shows that $1 \%$ increase in the use of agricultural inputs in the previous period leads to a $.096287 \%$ increase in current total agricultural export This result reiterates the importance of the use of agricultural inputs to enhance agricultural productivity and production of high value agricultural products, and hence increase total agricultural export of the countries.

Export diversification found to have positive and significance shows that $1 \%$ increase in export diversification leads to a $4.077307 \%$ increase in total agricultural export this implying that there is the more diversified economies that expect a stronger export performance and also it provides the opportunity to extend investment risk over a wider portfolio of economic sector which eventually increase income.

\subsubsection{The short run model.}

An error correction model is the short run model which reflects the current error in achieving the long run equilibrium relationship among variables. ECM is used to estimate the short run economic growth function and allows us to study the short run relationship among variable under consideration.

Table 2.5 Short run estimation results

\begin{tabular}{|l|l|l|l|l|lc|}
\hline \multicolumn{7}{|c|}{ Dependent variable agricultural export } \\
\hline variables & Coef. & Std. Err. & $\mathrm{t}$ & $\mathrm{P}>\mathrm{t}$ & \multicolumn{2}{c|}{$[95 \%$ Conf. Interval] } \\
\hline Dlnrgdp & 3.461821 & .76325 & $4.54^{*}$ & 0.001 & 1.798842 & 5.1248 \\
\hline Dlnreer & -.6864767 & .2329883 & $-2.95^{*}$ & 0.012 & -1.194115 & -.1788388 \\
\hline Dlnfert & .0556851 & .0349405 & 1.59 & 0.137 & -.0204436 & .1318139 \\
\hline Dopp & -1.127856 & 1.361049 & -0.83 & 0.423 & -4.093326 & 1.837614 \\
\hline Diq & -.0019852 & .0031018 & -0.64 & 0.534 & -.0087434 & .0047729 \\
\hline Dlndindex & 4.220564 & .7212788 & $5.85^{*}$ & 0.000 & 2.649032 & 5.792095 \\
\hline $\operatorname{lr}$ & -1.075467 & .2936723 & -3.66 & 0.003 & -1.715324 & -.4356097 \\
\hline cons & -.0055812 & .0592196 & -0.09 & 0.926 & -.1346097 & .1234473 \\
\hline
\end{tabular}

NB: * significant at $1 \%$

The error correction model is employed to correct for disequilibrium and determine the short run relationship between variables. The analysis of short run dynamics is often done by first eliminating trends in variables usually by differencing. In order to capture the adjustment towards the long run mode, the ECM incorporates the equilibrating error term (ECMt-1). As indicated in the about table $81.7 \%$ of the variation in the 
short run model is explained by the variables included in the model. The lagged error correction (Ecmt-1) indicates that $107 \%$ of the shock is adjusted in each year or the shock is eliminated in each year.

\section{Conclusion and policy recommendation}

\section{1 conclusions}

The central question investigated in this paper is whether or not agricultural export is significantly affected by the major selected explanatory variables such as gross domestic product, real effective exchange rate, fertilizer input, trade openness, and export diversification. To address this question, time serious data ranging from the year 1993 up to 2013 was utilized. The study used secondary data collected from different sources (NBE, MOFED, CSA, and UNCTAD). In this study agricultural export was used as dependent variable and the above mentioned variables expected to affect agricultural export performance of the country are used as explanatory variables.

The long run equation was estimated and according to the result real gross domestic product, fertilizer input and export diversification are positive and significantly affect the agricultural export performance of the country, and trade openness, real effective exchange rate and institutional quality is were found to be insignificant. The significant coefficient of real GDP shows that high production capacity determines the export potential utilization and total supply of agricultural export for the countries.

Also the significant coefficient of fertilizer input implying that the higher the use of agricultural input in may result in high agricultural production this in turn more products will be exported. So that the government should take measure to facilitate the agricultural input supply so as to transform the agricultural sector.

When we come to the significance coefficients of export diversification it imply that diversifying the export for portfolios could intensify and accelerate the economy growth and it helps to stabilize export earnings in the long run. Also for the country, export diversification protects the unpredictable declining trend in international price of primary exportable commodities.

Next, the Error Correction Model (ECM) was estimated to show the short run relationship between the dependent and explanatory variables. Accordingly, the regression result shows that the real gross domestic product, real effective exchange rate, and export diversification become significant have impact in the short run, on the other hand fertilizer input, trade openness and institutional quality are insignificant that means in the short run these variables have no impact on the agricultural export performance of Ethiopia.

\subsection{Policy implications}

The study tried to list out the major factors affecting the agricultural export performance of Ethiopia. The finding indicates that policy makers should give equal emphasis for demand and supply side determinants of agricultural export.

$>$ The positive and significant coefficients real GDP, suggests that macroeconomic policy reforms aimed at improving the growth of real GDP that should enhances the total agricultural export supply of the countries to the rest of the world.

$>$ the government should further facilitates the financial sector development and foreign direct investment in promoting export diversification because FDI encourage exports by boosting domestic capital for exports, serving to transfer technology and new product for exports, making access to new and large foreign markets easily and improving technical and management skills. Lowering barriers to firm's entry and reducing international trade cost, also constitute an important mechanism that help to diversify export markets.

$>$ The positive and significant coefficient of agricultural input reveals that lowering domestic trade barriers and subsidizing the import of modern intermediate agricultural inputs at a point in time will stimulate productivity and export in the following periods.

In sum, the above measures to be undertaken in order to reduce and eliminate the constraints deterring the performance of agricultural export sector are somewhat general. A closer look and detailed investigation is very important for achieving economic growth.

\section{REFERENCES}

Engle, R.F., and C.W.J. Granger (1987), "Cointegration and Error Correction: Representation, Estimation and

Testing”, Econometric 55, 251-276. Harriies, R. (1995), is using Cointegration analysis in econometric modeling, New York, Prentice Hall.

Fugazza, M. (2004), "Export Performance and Its Determinants: Supply and Demand Constraints", Policy Issues

In International Trade and Commodities Study Series Vol.1, No.26, Geneva, Swaziland.

G.S. Madala (1992)" Introduction to Econometrics" Second Edition, Macmillan publishing company, New York. Gujarati, Damodar (2004) "Basic Econometrics", 4th edition, The MacGraw - Hill Companies.

Ibrahim Worku (2007), "Determinants of primary commodity export in Sub-Saharan Africa" 
Kumar.J. and Siddhartha, N.S. (1997), “Technology, mark
policies for developing countries, Routledge, New York

Ministry of Foreign Affairs (2007), "Trade Promotion Manual for Ethiopian Diplomatic Missions "

NBE (National Bank of Ethiopia). Annual Reports, Various Issues

Samual T. (2012). "The determinant of agricultural export in Ethiopia, Addis Ababa University, Addis Ababa"

World Bank (2007), "World Development Indicators", World Bank, Washington, D.C. 